ACTA THERIOLOGICA

Vol. 33, 33: 451-465, 1988

\title{
Evaluation of Methods for Ground Survey of Feral Pigs and their Sign
}

\author{
Jim HONE
}

\begin{abstract}
Hone J., 1988: Evaluation of methods for ground survey of feral pigs and their sign. Acta theriol., 33, 33: 451-465. [With 6 Tables \& 2 Figs]

Methods for surveying the extent of feral pig rooting, feral pig dung and feral pigs counts were investigated in Namadgi National Park, Australia. The repeatability, precision and accuracy of the methods were examined over twelve months. Repeatable measures of pig rooting and counts of dung pellets were obtained. Rooting was a more accurate indicator of past feral pig presence than dung and counts of feral pigs. The results and their implications for surveying populations
\end{abstract} of feral pigs are discussed.

[School of Applied Science, Canberra College of Advanced Education, P.O. Box 1, Belconnen. ACT. 2615. Australia]

\section{INTRODUCTION}

Many methods have been used to survey feral pigs (Sus scrofa Linnaeus, 1758) or wild boar, but no universally accurate or precise method has been developed. Barrett (1982) outlined briefly some of the methods.

Indices of population density of feral pigs have been obtained by many methods. Track counts and drive counts (by beating) were used by Pucek et. al. (1975) Dzięciołowski (1976) and Bobek \& Perzanowski (1984) in Polish forests in winter snow. Dzięciołowski (1976) reported a significant $(p<0.05)$ but weak correlation $(0.389, \mathrm{df}=24)$ between the results of drive counts and the number of tracks of wild boar.

Other studies have used area counts (Hone \& Pedersen, 1980; Hone, 1983), spotlight strip transects (Hone, 1983), diurnal strip transects (Hone, in press), aerial strip transects (Pavlov et. al., 1981; Hone, 1983; Saunders \& Bryant, 1988; Wilson et al., 1987), bounty payments on pig snout (Giles, 1980; Woodall, 1983), dung counts (Ralph \& Maxwell, 1984), and the number of pigs killed (Diong, 1973). Line transects were used by Singer \& Ackerman (1981) in forests. The transects were used to obtain estimates of true density, by walking along existing trails, and converting observed density to true density by Eberhardt's (1968) power function. However Burnham et al. (1980) concluded that 
the power function was not generally useful as an estimator of true density. Barrett (1982) noted that many indices of pig abundance had been used but they have been rarely compared to known populations of feral pigs. He did not give an example.

Estimates of true density have been obtained by mark-recapture by Barrett (1971, 1978), Jezierski \& Myrcha (1975), Jezierski (1977), Andrzejewski \& Jezierski (1978), Giles (1980) Henry \& Conley (1978), Baber \& Coblentz (1986) and Coblentz \& Baber (1987). Coblentz \& Baber (1987) also used an area count and assumed it was accurate. Saunders \& Bryant (1988) used an index, manipulation, index method to estimate true population size.

In forests problems of sightability appear to limit use of many of the direct counting survey methods and those methods used may yield indices of abundance not true abundance, though this has not been experimentally tested. These problems have led to examination of measures of pig rooting to monitor trends in populations of feral pigs (Belden \& Pelton, 1975; Conley, 1977: Hone, in press). Survey data have several uses, in particular to monitor changes in feral pig density over time, to determine relationships between ground rooting and feral pig abundance, and to measure the effects of feral pig control on rooting and feral pig abundance. For these studies a method which measures the occurrence of rooting or accumulation of dung over a defined time period would be more sensitive than simply estimating the cumulative effects over a time period of unknown duration.

This study aimed to determine the repeatability and precision of three feral pig survey methods: line intercept estimation of ground rooting, plot counts of dung pellets, and area counts of pigs. Secondly the study aimed to determine relationships between the survey method results to investigate method accuracy and to assess the usefulness of the methods in control evaluation.

\section{METHODS}

The study occurred in the eastern half of Namadgi National Park, $\left(35^{\circ} 30^{\prime} \mathrm{S}\right.$, $149^{\circ} \mathrm{E}$ ), in the Australian Capital Territory. The area is disected by deep valleys and varies in altitude from about 800 to $1500 \mathrm{~m}$. Granitic rocks underlie nearly all the Park which is covered in Eucalyptus forest or woodland, with some broad grassland valleys (Anon, 1982). Annual average rainfall varies from $600 \mathrm{~mm}$ at low altitude, to $1000 \mathrm{~mm}$ at high altitude. The average daily maximum temperatures $\left({ }^{\circ} \mathrm{C}\right.$ in January were 25 and in July 9, and the average minimum temperatures in Janury were 10 and in July -2 . Snowfalls are common in winter (June, July, August) and snow stays on the ground for several weeks at high altitude.

Seven sites were selected with restricted randomisation in the park; Cotter 
Gap, Nursery Swamp, Honeysuckle Creek, Brandy Flat, Shanahans Falls Creek, Boboyan Pine Forest, and Boboyan (Naas Creek). Sites selected were at least $5 \mathrm{~km}$ apart to minimize movement effects by feral pigs between sites. That distance was chosen on the basis of limited radio-tracking data (Terrill, pers. comm.) for feral pigs in the park. Rainfall data were recorded monthly at each site and temperature data collected at Glendale Crossing in the centre of the area.

Each site consisted of $4 \mathrm{~km}^{2}$ with 100 permanent plots in each site. The number of plots was chosen on the basis of preliminary survey work that showed 48 plots was insufficient to get repeatable dung counts, and to get greater precision in the stimate of the proportion of a site rooted by feral pigs. Plots were randomly located with respect to placement and orientation, except plots did not overlap (sampling without replacement) and secondly the distance between plots did not exceed $35 \mathrm{~m}$ to facilitate finding plots. Each plot was $20 \mathrm{~m}^{2}$, the same size as used by Ralph \& Maxwell (1984) and marked with numbered pegs at the ends of the main long axis of the $10 \mathrm{~m} \times 2 \mathrm{~m}$ 'plot.

Rooting was recorded using a line intercept method (Lucas \& Seber, 1977), with the start and end of each area of rooting measured directly under a tape measure held between the two plot pegs. An area was recorded as rooted iff there were obvious signs of ground disturbance by feral pigs and the vegetative ground cover was less than that of surrounding nondisturbed areas.

Dung pellets were counted on a $1 \mathrm{~m}$ strip either side of this centreline tape. The number of dung pellets was recorded then the plot was cleared of pig dung. Only dung that were intact were counted. No attempt was made to age dung. Dung of feral pigs was differentiated from that of other species on the basis of shape (oval to lobed), composition (fibrous, heterogeneous), colour (black) and odour (putrid). For adult pigs that was very easy, however dung of subadult (6$12 \mathrm{mo})$ pigs required careful examination to avoid confusion with the dung of kangaroos. Dung of juvenile $(<6 \mathrm{mo})$ feral pigs was not detected during the study. Fresh dung pellets were placed outside but near the plot and checked each month to determine disappearance rates. Dung were classed as present if each pellet was still intact and could be picked up without disintegrating.

Feral pigs seen at each site were recorded and age and sex recorded. As the plots were clustered in each site the area over which pigs were observed was not the whole of each site, but totalled $1 \mathrm{~km}^{2}$. Study in 1984 (Hone, in press) indicated that there were insufficient sightings of feral pigs to use a line or strip transect method for estimating true density, so area counts were used. Burnham et al., (1980) recommended that at least 40 animals needed to be observed to use transect methods, and I did not expect to see that meny each month.

Sampling was conducted monthly from June 1985 to May 1986 inclusive, to determine changes within seasons and to allow sufficient time for rooting extent to change and dung to accumulate. Measurement of dung pellet decay continued until December 1986 to allow estimation of decay regressions with a minimum of four degrees of freedom for each month of study. Preliminary work in March and April 1985 showed that most feral pig dung pellets lasted longer than one month, in contrast to the disappearance of most dung in Hawaii in two weeks (Ralph \& Maxwell, 1984).

The repeatability within months of rooting measurements per site was determined by independently measuring each of 700 plots, and testing the difference using a paired Student's $t$ test (Snedecor \& Cochran, 1967). The re- 
peatability between months of dung counts was tested by Chi-square analysis by comparing the frequency distributions of the number of dung pellets per plot for two successive months. Data from 400 plots were used.

To examine the application of the data for predicting the extent of rooting or abundance of dung pellets, relationships between the extent of rooting and abundance of dung, and the frequency of occurrence of either rooting or dung were determined by least squares regression forced through the origin. The $x$ variable was either the frequency of occurrence or an index calculated from the first term of a Poisson series (Caughley, 1980), where the index (I) was:

$$
I=-\ln (1-\mathbf{f})
$$

where $f$ was the proportion of plots with rooting (or dung). For regression it was assumed that the standard deviation of each value of $x$ was proportional to that $x$ (Snedecor \& Cochran, 1967). The Poisson transformation was investigated as there is commonly a curvilinear relationship between the frequency of occurrence data and density indices (Caughley, 1980). Batcheler (1973) reported significant correlations between density of possum (Trichosurus vulpecula Kerr, 1792) dung and an index of dung density calculated from the first term of a Poisson series.

The frequency distributions of rooting per plot (length of rooting $/ 10 \mathrm{~m}$ ) were compared to a negative exponential function fitted by least squares regression after transformation to natural logarithms:

$$
y=a e^{-\mathrm{xb}}
$$

For the rooting data $x$ was the midpoint of each rooting class.

The decay of dung pellets each month was compared to a modified exponential function, fitted by least squares regression after rearranging the equation and transformation to common logarithms:

$$
y=100-a x^{\mathrm{b}}
$$

where $y$ was the percentage of dung pellets remaining, but did not include the initial data $(x=0, y=100 \%)$ and $x$ was the number of months since reference dung were established. This solves to the initial starting point $(x=0, y=100)$. For the regression $0<a<100$, and $b$ is not equal to 1 (otherwise the regression is a straight line).

The numbers of dung per plot per month were compared to a Poisson distríbution by a Chi-square goodness-of-fit test (Snedecor \& Cochran, 1967). The number of dung pellets per site corrected for decay $(C D)$ was estimated from;

$$
C D=\left(M \ln \left(f_{1} / f_{2}\right)\right) /\left(1-\left(f_{2} / f_{1}\right)\right)
$$

where $M$ was the number of dung pellets counted after one month, $f_{1}$ the number of reference dung pellets at the start of the month, and $f_{2}$ the number of reference dung pellets still present at the end of the month (Hill 1981). 


\section{RESULTS}

\subsection{Rooting}

The average difference in rooting at each site between each repeated measurement was 0.0 ( $\pm 0.57 \mathrm{SE})$, which was obviously not significantly different from zero $(t=0.0, \mathrm{df}=6, p>0.05)$. The most frequent length of rooting was zero. The frequency distribution of rooting extent per plot (length of rooting/10 m) was of negative exponential form (Fig. 1). A negative exponential equation fitted to each month's data gave highly significant $(p<0.01)$ correlations (Table 1$)$.

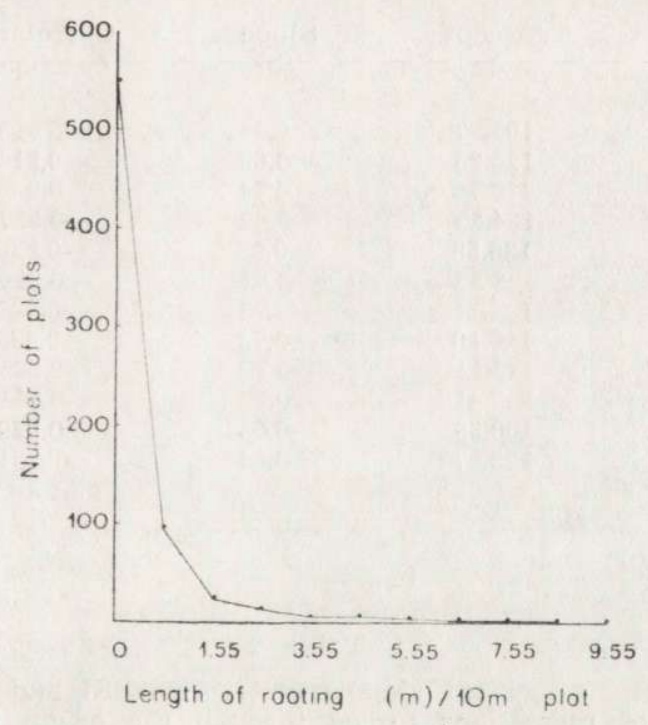

Fig. 1. The frequency distribution of the lengths of feral pig rooting $(\mathrm{m})$ per $10 \mathrm{~m}$ of plot. Data are the average values over the 12 month study. The total number of plots measured per month was 700 .

The percentage of the ground rooted over by feral pigs averaged $2.7 \%$ during the 12 months. The percentage differed between sites and months being highest at Boboyan pine forest $(7.4 \%)$ and lowest at Brandy Flat $(0.1 \%)$ and highest seasonally in October $(3.6 \%)$ and lowest in June and January $(2.2 \%)$. The percentage of plots with rooting varied among months from $18.1 \%$ to $26.6 \%$. The ratio of the standard error to the mean percentage ranged from $6.3 \%$ to $8.0 \%$.

The actual extent of rooting per site (rooting $\mathrm{m} / 1000 \mathrm{~m}$ ) was sig- 
nificantly $(p<0.05)$ correlated with an index of rooting extent calculated from the percentage of plots with rooting using the first term of a Poisson series (Table 2), and was significantly correlated each month with the percentage of plots with rooting (Table 3 ).

Table 1

The intercepts, slopes and correlation coefficients of a negative exponential equation fitted to the frequency distribution of rooting per plot for each month. Degrees of freedom vary between months as a zero occurrence could not be included in the regres$\operatorname{sion}(\ln \mathrm{O}=-\infty)$. All correlations were significant at the 0.01 level.

\begin{tabular}{lcccc}
\hline Month & $\begin{array}{c}\text { Intercept } \\
\text { (a) }\end{array}$ & $\begin{array}{c}\text { Slope } \\
\text { (b) }\end{array}$ & $\begin{array}{c}\text { Correlation } \\
\text { coefficient }\end{array}$ & df \\
\hline June & 105.57 & -0.64 & -0.915 & 7 \\
July & 125.25 & -0.69 & -0.914 & 7 \\
August & 120.78 & -0.64 & -0.936 & 8 \\
September & 124.59 & -0.62 & -0.927 & 8 \\
October & 136.55 & -0.62 & -0.939 & 8 \\
November & 123.52 & -0.65 & -0.914 & 6 \\
December & 133.74 & -0.73 & -0.927 & 7 \\
January & 126.10 & -0.73 & -0.885 & 6 \\
February & 133.11 & -0.70 & -0.935 & 7 \\
March & 133.41 & -0.73 & -0.911 & 7 \\
April & 130.89 & -0.66 & -0.949 & 8 \\
May & 123.97 & -0.64 & -0.931 & 8 \\
\hline
\end{tabular}

Table 2

The slopes, associated standard errors (SE) and Student's $t$ statistics of regressions forced through the origin between the percentage of ground rooted by pigs at each site and an index of rooting extent. The index was calculated from the first term of a Poisson series using the percentage of plots with rooting at each site. ${ }^{*} p<0.05,{ }^{* *} p<0.01$.

\begin{tabular}{|c|c|c|c|c|c|}
\hline Month & Slope & SE & $\mathrm{t}$ & df & Signif \\
\hline June & 8.85 & 2.38 & 3.72 & 6 & $* *$ \\
\hline July & 8.61 & 1.89 & 3.72 & 6 & $* *$ \\
\hline August & 8.83 & 1.73 & 4.56 & 6 & ** \\
\hline September & 8.13 & 1.50 & 5.42 & 6 & $* *$ \\
\hline October & 7.98 & 1.73 & 4.61 & 6 & $* *$ \\
\hline November & 8.03 & 1.46 & 5.50 & 6 & $* *$ \\
\hline December & 8.22 & 1.89 & 4.35 & 6 & $* *$ \\
\hline January & 8.12 & 1.65 & 4.92 & 6 & $* *$ \\
\hline February & 9.88 & 1.60 & 6.18 & 6 & $* *$ \\
\hline March & 9.52 & 2.18 & 4.37 & 6 & $* *$ \\
\hline April & 9.08 & 2.22 & 4.09 & 6 & $* *$ \\
\hline May & 8.31 & 2.55 & 3.26 & 6 & $*$ \\
\hline
\end{tabular}


There was no significant difference $\left(\chi^{2}=1.744, \mathrm{df}=2, p>0.05\right)$ between the repeated counts in the number of dung pellets per plot from June to July 1985 .

Table 3

The slopes, associated standard errors (SE) and Student's $t$ statistics of regressions forced through the origin between the percentage of ground rooted by pigs at each site and the percentage of plots with rooting at each site. ${ }^{*} p<0.05,{ }^{* *} p<0.01$.

\begin{tabular}{lccccc}
\hline Month & Slope & SE & $t$ & df & Signif \\
\hline June & 0.10 & 0.03 & 3.33 & 6 & $*$ \\
July & 0.10 & 0.02 & 5.00 & 6 & $* *$ \\
August & 0.10 & 0.02 & 5.00 & 6 & $* *$ \\
September & 0.10 & 0.02 & 5.00 & 6 & $* *$ \\
October & 0.10 & 0.02 & 5.00 & 6 & $* *$ \\
November & 0.09 & 0.02 & 4.50 & 6 & $* *$ \\
December & 0.10 & 0.03 & 3.33 & 6 & $* *$ \\
January & 0.09 & 0.02 & 4.50 & 6 & $* *$ \\
February & 0.12 & 0.02 & 6.00 & 6 & $* *$ \\
March & 0.11 & 0.03 & 3.67 & 6 & $* *$ \\
April & 0.11 & 0.03 & 3.67 & 6 & $*$ \\
May & 0.10 & 0.03 & 3.33 & 6 & $*$ \\
\hline
\end{tabular}

3.2. Dung

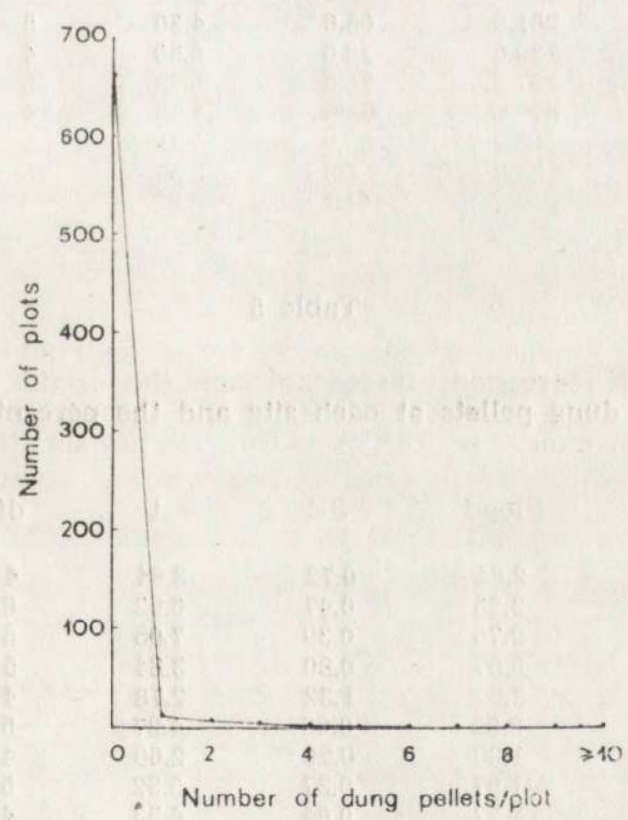

Fig. 2. The frequency distribution of the number of feral pig dung pellets per plot per month. Data are the average values for the 12 month study. The total number of plots per month on which dung pellets were counted was 700 . 
The frequency distribution of dung pellets per plot was highly skewed, with the most common number being 0 , then 1 , then 2 (Fig. 2). The frequency distribution was significantly different $(p<0.05)$ from a Poisson distribution in each month. The percentage of plots with dung pellets varied among months from $1.4 \%$ to $8.3 \%$. The ratio of the standard error to the mean percentage ranged from $12.6 \%$ to $31.7 \%$. The mean number of dung pellets per plot per month was 0.16 and the mean varied among months from 0.02 to 0.31 The ratio of the standard error to the mean ranged from $14.3 \%$ to $50.0 \%$.

Table 4

The slopes, associated standard errors (SE) and Student's $t$ statistics of regressions forced through the origin between the number of dung pellets at each site and an index of dung abundance. The index was calculated from the first term of a Poisson series using the percentage of plots with feral pig dung. ${ }^{*} p<0.05,{ }^{* *} p<0.01$

\begin{tabular}{lcrccc}
\hline Month & Slope & SE & $t$ & df & Signif \\
\hline June & 268.9 & 58.1 & 4.63 & 4 & $* *$ \\
July & 320.7 & 47.3 & 6.78 & 6 & $* *$ \\
August & 263.1 & 33.2 & 7.93 & 5 & $*$ \\
Septembey & 295.8 & 80.1 & 3.69 & 5 & $*$ \\
October & 366.9 & 132.2 & 2.78 & 4 & $*$ \\
November & 281.9 & 65.6 & 4.30 & 5 & $* *$ \\
December & 130.0 & 20.0 & 6.50 & 4 & $* *$ \\
January & 197.2 & 36.6 & 5.39 & 5 & $* *$ \\
February & 276.6 & 63.6 & 4.35 & 4 & $*$ \\
March & 186.3 & 25.9 & 7.19 & 5 & $* *$ \\
April & 183.8 & 51.3 & 3.58 & 5 & $*$ \\
May & 239.7 & 41.1 & 5.83 & 4 & $* *$ \\
\hline
\end{tabular}

Table 5

The slopes, associated standard errors (SE) and Student's $t$ statistics of regressions forced through the origin between the number of dung pellets at each site and the percentage of plots with dung. ${ }^{*} p<0.05,{ }^{* *} p<0.01$, NS not significant.

\begin{tabular}{|c|c|c|c|c|c|}
\hline Month & Slope & $\mathrm{SE}$ & $t$ & df & Signif \\
\hline June & 2.84 & 0.72 & 3.94 & 4 & $*$ \\
\hline July & 3.25 & 0.47 & 6.92 & 6 & $* *$ \\
\hline August & 2.75 & 0.39 & 7.05 & 5 & $* *$ \\
\hline September & 3.07 & 0.80 & 3.84 & 5 & $\bullet$ \\
\hline October & 3.67 & 1.32 & 2.78 & 4 & $*$ \\
\hline November & 2.82 & 0.66 & 4.27 & 5 & $*$ \\
\hline December & 1.30 & 0.20 & 2.60 & 4 & NS \\
\hline January & 1.97 & 0.37 & 5.32 & 5 & $* *$ \\
\hline February & 2.77 & 0.64 & 4.33 & 4 & $*$ \\
\hline March & 1.89 & 0.27 & 7.00 & 5 & $* *$ \\
\hline April & 1.91 & 0.59 & 3.24 & 5 & $*$ \\
\hline May & 2.43 & 0.41 & 5.93 & 4 & ** \\
\hline
\end{tabular}


The number of dung pellets per site for each month was significantly correlated with an index of dung abundance calculated from the first term of a Poisson series (Table 4). Similarly the number of dung pellets was significantly correlated with the percentage of plots with dung (Table 5), except for December.

The percentage of dung pellets remaining each month declined exponentially in each month (Table 6) though the rates of decay varied among months. The coefficient $a$ was very high in October and December and the coefficient $b$ low in the same months. The average value of $b$ was $0.67( \pm 0.12 \mathrm{SE})$ which was significantly different to 1 $(t=2.75, \mathrm{df}=11, p<0.05)$. The average value of the coefficient $a$ was significantly different from $0(t=4.62, \mathrm{df}=11, p<0.001)$ and from 100 $(t=10.15, \mathrm{df}=11, p<0.001)$.

\section{Table 6}

The coefficients $(a, b)$ and correlation coefficients of modified exponential regressions between the percentage of dung pellets remaining and the months since reference dung were stablished. Degrees of freedom (df) differ between months as dung disappeared after differing times ${ }^{*} p<0.05,{ }^{* *} p<0.01$.

\begin{tabular}{lrrrrr}
\hline $\begin{array}{l}\text { Month dung } \\
\text { established }\end{array}$ & $a$ & $b$ & $\begin{array}{l}\text { Correlation } \\
\text { coefficient }\end{array}$ & df & Signif \\
\hline June & 4.71 & 1.43 & 0.935 & 10 & $* *$ \\
July & 15.43 & 0.78 & 0.940 & 13 & $* *$ \\
August & 8.62 & 1.06 & 0.849 & 13 & $* *$ \\
September & 36.71 & 0.43 & 0.917 & 12 & $* *$ \\
October & 74.44 & 0.13 & 0.836 & 8 & $* *$ \\
November & 44.56 & 0.39 & 0.695 & 10 & $*$ \\
December & 72.97 & 0.16 & 0.783 & 5 & $*$ \\
January & 16.98 & 0.69 & 0.985 & 8 & $* *$ \\
February & 41.90 & 0.36 & 0.978 & 6 & $* *$ \\
March & 22.94 & 0.68 & 0.987 & 6 & $* *$ \\
April & 21.28 & 0.73 & 0.989 & 5 & $* *$ \\
May & 14.64 & 1.16 & 0.960 & 4 & $* *$ \\
\hline
\end{tabular}

\subsection{Pigs}

The observed density of feral pigs in the study area was 0.89 $( \pm 0.27 \mathrm{SE}) / \mathrm{km}^{2}$. Of pigs observed $(85)$ in the seven sites $44(51.8 \%)$ were adults, $11(12.9 \%)$ sub-adults and $30(35.3 \%)$ juveniles. Of pigs that could be sexed 17 were male and 19 female.

\subsection{Relationships between Rooting and Dung}

When calculated between months there was no significant correlation between the percentage of the ground rooted and the average number of dung pellets per site $(r=0.082, \mathrm{df}=10, \quad p>0.05)$, or the corrected average number of dung pellets $(r=0.269, \mathrm{df}=10, p>0.05)$. 
When calculated between sites there was no significant correlation between the percentage of the ground rooted by pigs and the average number of dung pellets $(r=0.053, \mathrm{df}=5, p>0.05)$, or the corrected average number of dung pellets $(r=0.043, \mathrm{df}=5, p>0.05)$.

The change in the percentage of ground rooted between successive months was significantly correlated with the corrected dung counts $(r=0.628, \mathrm{df}=9, p<0.05)$, but not sinificantly correlated $(p>0.05)$ with rainfall during the month $(r=-0.324, \mathrm{df}=9)$, the previous percentage of the ground rooted by pigs $(r=-0.564, \mathrm{df}=9)$, average minimum temperature $(r=-0.311, \mathrm{df}=9)$, average maximum temperature ( $r=$ $=-0.168, \mathrm{df}=9)$, average temperature $(r=-0.211, \mathrm{df}=9)$, or the product of the average temperature and rainfall $(r=-0.540, \mathrm{df}=9)$.

The change in the percentage of plots with rooting between succesive months was significantly correlated with the corrected dung counts $(r=0.687, \mathrm{df}=9, p<0.05)$, but not significantly correlated $(p>0.05)$ with rainfall during the month $(r=0.336, \mathrm{df}=9)$, average minimum temperature $(r=-0.316, \mathrm{df}=9)$, average maximum temperature $(r=-0.118$, $\mathrm{df}=9)$, average temperature $(r=-0.204, \mathrm{df}=9)$, or the product of average temperature and rainfall $(r=-0.604, \mathrm{df}=9)$.

\subsection{Relationships between Rooting and Pigs}

The percentage of ground rooted by pigs among months was not significantly correlated with observed pig density $(r=-0.089, \mathrm{df}=10)$. Between sites the percentage of each site rooted by pigs was not significantly correlated with observed pig density averaged over months $(r=-0.037, \mathrm{df}=5)$. The change between successive months in the percentage of ground rooted was not significantly correlated to observed pig density $(r=0.077, \mathrm{df}=9)$.

At Shanahans Falls Creek where more feral pigs were counted than at other sites, there was no significant correlation $(r=-0.237$, $\mathrm{df}=10$ ) between the percentage ground rooted and observed density of pigs at the end of a month.

\subsection{Relationships between Dung and Pigs}

There was no significant correlation between the number of dung per month and the observed density of feral pigs $(r=0.049, \mathrm{df}=10)$. The relationship was explored in more detail at Shanahans Falls Creek where pigs could be more easily observed and were not disturbed. 
There was no significant correlation $(r=0.257, \mathrm{df}=10)$ between the number of dung per month and observed pig density at the end of the month. However when juvenile pigs were excluded from the analysis and observed pig densities at the start and end of each month averaged, then there was a significant correlation between dung pellets counted and average observed density of adult and subadult pigs $(r=0.844, \mathrm{df}=10, p<0.01)$. The regression equation was:

Dung pellets $/$ month $=8.95+16.33$ (mean adult + subadult pigs).

There was a significant correlation between the corrected count of dung pellets and average observed adult and subadult pig density $(r=0.844, \mathrm{df}=10, p<0.01)$. The regression equation was:

Corr. dung pellets/month $=12.83+16.46$ (mean adult + subadult pigs).

In both cases the regression equations had an intercept above zero indicating a bias in the observed pig density - dung was accumulating but no pigs were sighted.

\section{DISCUSSION}

The results show that repeatable measures of rooting and counts of dung were obtained by the methods used. Rooting was a more accurate indicator of past feral pig presence than dung counts, as rooting occurred when no dung occurred, and dung counts were more accurate in showing pig presence over a month than one or two counts of pigs per month. For the same number of plots measured, the percentage of plots with rooting was a more precise measure than the percentage of plots with dung. The results in this study expand the range of survey methods available for feral pigs and their sign.

The extent of rooting in this study averaged $2.7 \%$ and varied between months from $2.2 \%$ to $3.6 \%$. This extent was similar to that reported for a Polish forest $(1 \%-10 \%)$ by Jezierski \& Myrcha (1975) but lower than that reported for an Hawaiian forest $(6 \%-11 \%)$ by Ralph \& Maxwell (1984) and parts of Great Smoky Mountains National Park, Tennessee $(0.3 \%-80 \%)$ by Singer $(1981)$ or an Hawaiian forest $(14 \%$ $38 \%$ ) reported by Cooray \& Mueller-Dombois (1981).

The negative exponential frequency distribution of rooting per plot probably reflects different searching patterns by feral pigs. The large number of short lengths of rooting may have been sites of searching 
for food, and the longer lengths of rooting were sites where food was found.

The lack of correlation between the extent of rooting and dung counts or pig counts supports the model presented by Hone (in press), that predicted a lack of a significant correlation. The assumption of Belden \& Pelton (1975), Conley (1977) and Giles (1980), that the extent of rooting is positively correlated with population density, is not correct. The lack of correlation may also result from a lack of time period on the measure of rooting compared to that of dung which accumulated over one month.

In contrast the monthly change in the extent or frequency of rooting was positively correlated with the abundance of pig dung. Further research needs to be done to distinguish the effects of climate from the effects of pig abundance on the monthly change in the extent or frequency of pig rooting.

The observed population density of feral pigs in Namadgi National Park $\left(0.89 / \mathrm{km}^{2}\right)$ was lower than that reported for mountain forests $(2-$ $9 / \mathrm{km}^{2}$ ) in Tennessee and for forests $\left(19-79 / \mathrm{km}^{2}\right)$ in Hawaii (Singer 1981). The observed density was similar to that reported by Hone (in press) of $1.0 / \mathrm{km}^{2}$ in the same mountain forests in Australia. The precision of the estimate was higher in this study $(\mathrm{CV}=30 \%)$ than that reported by Hone (in press) $(\mathrm{CV}=50 \%)$.

The counts of dung pellets in the present study were on average much lower than those reported in Hawaiian forests. Average dung pellets $/ 20 \mathrm{~m}^{2}$ were 0.16 in this study and $0.47-1.65$ (Ralph \& Maxwell, 1984) and 83.3-150 in Hawaii (Cooray \& Mueller-Dombois, 1981). The latter counts have been corrected to the same plot size as used in the present study. The percentage of plots with pig dung ranged from $1.4 \%$ $-8.3 \%$ in the present study compared to $4.0 \%-17.5 \%$ in Hawaii (Cooray \& Mueller-Dombois, 1981).

The number of dung counted declined over summer even when corrected for decay. A possible explanation is that the pigs moved to higher altitude in summer as suggested by Boreham (1981) and reported for feral pigs in the USA (Belden \& Pelton, 1975; Singer et al., 1981)

Comparison of the population density and dung counts in the present study suggests that the pig counts were underestimates. The average count of dung pellets was $0.16 / 20 \mathrm{~m}^{2} /$ month which is equivalent to 267 dung pellets $/ \mathrm{km}^{2} /$ day. As the observed pig density was $0.89 / \mathrm{km}^{2}$ then those pigs must produce 300 dung pellets/pig/day. No estimates of the defecation rates of feral pigs have been published though this rate is considered an overestimate. This is supported by the regression be- 
tween the dung counts and counts of pigs. Even when no feral pigs were counted dung pellets were still counted.

The rates of decay of dung pellets in the present study were lower than those reported for Hawaii (Ralph \& Maxwell, 1984). This may have been associated with lower temperatures and rainfall in the Australian forests.

The significant regressions between the extent of rooting and percentage of plots with rooting, and the abundance of dung and the percentage of plots with dung, suggest that detailed measurement of rooting or counts of dung pellets are not necessary. Only the percentage of plots with rooting or with dung need to be recorded. Such a recording system reduced field time from four hours per site to 1.5 hours per site when used in July 1986 after this study.

Acknowledgements: I thank the ACT Parks and Conservation Service for permission to work in Namadgi National Park, and the Canberra College of Advanced Education, College Research Fund, and the Department of Forestry of the Australian National University for funding the research. The Bureau of Meteorology supplied the temperature data. Dr. P. O'Brien and Dr. M. Tanton made useful comments on a draft manuscript, and F. Krikowa drew the figures.

\section{REFERENCES}

1. Andrzejewski R. \& Jezierski W., 1978: Management of a wild boar population and its effects on commercial land. Acta theriol., 23: 309-339.

2. Anon. 1982: Ecological Resources of the ACT. Technical paper 42, National Capital Development Commission.

3. Baber D. W. \& Coblentz B. E., 1986: Density, home range, habitat use and reproduction in feral pigs on Santa Catalina Island. J. Mammal., 67: 512-25.

4. Barrett R. H., 1971: Ecology of the feral hog in Tehama county, California. Ph.D. thesis, University of California, Berkeley.

5. Barrett R. H., 1978: The feral hog on the Dye Creek ranch, California. Hilgardia, 46: 283-355.

6. Barrett R. H., 1982: Wild pigs. [In: "CRC Handbook of Census Methods for Terrestrial Vertebrates.” D.E. Davis ed.] CRC Press: 243-244. Florida.

7. Batcheler C. L., 1973: Estimation of population density changes. [In: "Assessment and Management of Introduced Animals in New Zealand Forests". J. Orwin ed.] N.Z. Forest Service: 136-152. F.R.I. Symposium No. 14.

8. Belden R.C. \& Pelton M. R., 1975: European wild hog rooting in the mountains of east Tennessee. Proc. Twenty-ninth Annual Conf. Southeast Assoc. Game and Fish Commissioners. 665-671. Saint Louis, Missouri.

9. Bobek B. \& Perzanowski K., 1984: Energy and matter flow through ungulates. [In: "Forest Ecosystems in Industrial Regions." W. Grodziński, J. Weiner \& P. F. Maycock ed.] Springer-Verlag: 121-125. Berlin.

10. Boreham P., 1981: Some aspects of the ecology and control of feral pigs in the Gudgenby Nature Reserve. Conserv. Memo. No. 10. ACT Conservation Service.

11. Burnham K. P., Anderson D. R. \& Laake J. L., 1980: Estimation of density from line transect sampling. Wildlife Monograph, 72. 
12. Caughley G., 1980: Analysis of Vertebrate Populations. Reprinted with corrections. Wiley, New York.

13. Coblentz B. E. \& Baber D. W., 1987: Biology and control of feral pigs on Isla Santiago, Galapagos, Ecuador. J. Applied Ecol., 24: 403-418.

14. Conley R.H., 1977: Management and research of the European wild hog in Tennessee. [In: "Research and Management of Wild Hog Populations." G.W. Wood ed.] Belle Baruch Forest Sci. Inst.: 67-70. South Carolina.

15. Cooray R. G. \& Mueller-Dombois D., 1981: Feral pig activity. [In: "Island Ecosystems. Biological Organization in Selected Hawaiian Communities." D. Mueller-Dombois, K.W. Bridge \& H.L. Carson ed.] Hutchinson res. Publish. Co.: 309-319. Stroudsburg.

16. Diong C.H., 1973: Studies on the Malayan wild pig in Perak and Johore. Malay. Nat. J., 26: 120-151.

17. Dzięciolowski R., 1976: Estimating ungulate numbers in a forest by track counts. Acta theriol., 21: 217-222.

18. Eberhardt L.L., 1968: A preliminary appraisal of line transects. J. Wild. Manage., 32: $82-88$.

19. Giles J.R., 1980: The ecology of feral pigs in NSW. Ph.D. thesis, University of Sydney.

20. Henry V. G. \& Conley R. H., 1978: Survival and mortality in European wild hogs. Proc. Thirty-second Annual Conf. Southeast Assoc. Fish and Wildlife Agencies. 93-99. Hot Springs, Virginia.

21. Hill G.J.E., 1981: A study of grey kangaroo density using pellet counts. Aust. Wild. Res., 8: 237-244.

22. Hone J., 1983: A short-term evaluation of feral pig eradication at Willandra in western NSW. Aust. Wildl. Res., 10: 269-275.

23. Hone J., in press. Feral pigs in mountain forests: distribution, abundance and environmental correlates of pig rooting. Aust. J. Ecol.

24. Hone J. \& Pedersen. H., 1980: Changes in a feral pig population after poisoning. Proc. Ninth Vertebrate Pest Confer. California. 176-182.

25. Jezierski W., 1977: Longevity and mortality rate in an population of wild boar. Acta theriol., 24: 137-348.

26. Jezierski W. \& Myrcha A., 1975: Food requirements of a wild boar population. Polish ecol. Studies 1: $61-83$.

27. Lucas H.A. \& Seber G. A. F., 1977: Estimating coverage and particle density using the line intercept method. Biomerika 64 : 618-622.

28. Pavlov P., Hone J., Kilgour R. \& Pedersen H., 1981: Predation by feral pigs on merino lambs at Nyngan, NSW. Aust. J. exper. Agric. Anim. Husb., 12: $570-574$.

29. Pucek Z., Bobek B., Łabudzki L., Miłkowski L., Morow K. \& Tomek A., 1975: Estimates of density and number of ungulates. Polish ecol. Studies 1: 121136.

30. Ralph C.J. \& Maxwell B. D., 1984: Relative effects of human and feral hog disturbance on a wet forest in Hawaii. Biol. Conserv. 30: 291-303.

31. Saunders G. \& Bryant H. 1988: The evaluation of a feral pig eradication programme during a simulated exotic diseaese outbreak. Aust. Wildl. Res., 15: $73-82$.

32. Singer F. J., 1981: Wild pig populations in the National Parks. Envir. Manage., 5: $263-270$.

33. Singer F. J. \& Ackerman B. B., 1981: Food availability, reproduction and con- 
dition of European wild boar in Great Smoky Mountains National Park. US National Park Service Research/Resources Management Report No. 43.

34. Singer F. J., Otto D. K., Tipton A. R. \& Hable C. P., 1981: Home ranges, movements and habitat use of European wild boar in Tennessee. J. Wildl. Manage., 45: 343-355.

35. Snedecor G.W. \& Cochran W. G., 1967: Statistical Methods. 6th. ed. Iowa State Univ. Press, Iowa.

36. Wilson G. R., Hill G. J. E. \& Barnes A, 1987: An aerial survey of feral pigs and emus in south eastern Queensland. Aust. Wildl. Res. 14: 515-520.

37. Woodall P. F., 1983: Distribution and population dynamics of dingoes (Canis familiaris) and feral pigs (Sus scrofa) in Queensland, 1945-1976. J. Applied Ecol., 20: 85-95.

Received 10 March 1988, Accepted 13 May 1988.

Jim HONE

OCENA METOD SZACOWANIA LICZEBNOSCI ZDZICZAŁYCH SWIŃ

Streszczenie

Testowano metody określania rozmiaru buchtowania, ilości odchodów oraz liczebności dzikich świń domowych w Parku Narodowym Namadgi w Australii Powtarzalność, dokładność i przewidywalność metod sprawdzono w okresie dwunastu miesięcy. Znaleziono powtarzalne miary wielkości rycia i liczby odchodów.

Slady rycia były lepszym wskaźnikiem poprzedniej obecności świń niż odchody. Liczenie odchodów dawało dokładniejsze wyniki niż bezpośrednie liczenie świń. Dyskutowane jest znaczenie wyników badań dla szacowania wielkości populacji dzikich świń. 